\author{
Centre for Central Banking Studies, Bank of England \\ CCBS Expert Forum: Central Bank Finances and Impact on Independence
}

September 2005

\title{
Securing financial independence in the legal basis of a central bank
}

Fabian Amtenbrink ${ }^{1}$

\section{Introduction}

While the economic and legal discussions of central bank independence arguably peaked in the 1990's, often inspired by the creation of the European System of Central Banks (ESCB) and the European Central Bank (ECB) and the related institutional reforms in a number of European Union countries, the topic remains on the agenda, not only for academics. This may first of all be explained by the fact that many but certainly far from all countries have accepted and implemented the philosophy underlying central bank independence. Thus, in some instances preference continuous to go out to a more direct influence on monetary policy and at times - direct access to central bank money. Moreover, even if the ratio behind this basic institutional setup for central banks is recognized, the implications for the concrete legal arrangements remain subject of debates. This is in particular the case since the realization has set in more prominently that in a democratic society, central bank independence needs to be counterbalanced by mechanisms ensuring the accountability of the central bank for the performance of the tasks with which it is entrusted.

The economic ratio for central bank independence has been demonstrated extensively. Together with institutional, functional and organizational independence, financial independence constitutes one of the cornerstones of central bank independence. In broad terms financial independence may be defined as referring to the legal and practical arrangements

\footnotetext{
${ }^{1}$ Professor of European Union Law, Faculty of Law, Erasmus University Rotterdam. At the time of the presentation of the original paper with the title The impact of central bank finances on independence and accountability, the author was affiliated with the University of Groningen.

${ }^{2}$ Cf. e.g. P. Stella, Do Central Banks Need Capital?, International Monetary Fund Working Paper WP/97/83.
} 
identifying the finances of a central bank and the extent to which the bank is subject to outside influence in this regard.

In the (legal) debate on central bank accountability, arguably arrangements relating to central bank finances have sometimes been treated in a rather step motherly fashion. ${ }^{3}$ Yet, with the wider debate on good governance structures having reached central banking, more attention is paid to such detailed arrangements. Indeed, the term governance does not only summarize the processes of decision-making and decision implementation, but also includes the underlying institutional structures which affect these processes and shape the way in which a central bank is operated. Moreover, it defines the relationship among the several stakeholders involved, namely executive government, parliament and the central bank itself. The arrangements surrounding the managing of the financial affairs of a central bank form a key element in determine the characteristics of a central bank in this regard.

Hereafter, this contribution focuses on and aims at providing an overview on the impact on central bank independence of the legal arrangements relating to several aspects of central bank finances. In observing financial independence, central bank studies regularly focus on the arrangements relating to government direct and indirect access to central bank credits. This may be explained with the fact that unrestricted government access to central bank money is at odds with what is widely believed to be the principal task of a central bank that is to provide monetary stability. ${ }^{4}$ While government access to central bank money undoubtedly has an impact on the financial position of the central bank, this contribution focuses on those elements, which are arguably more directly linked to the financial position of a central bank, including capitalization and recapitalization, the determination of the central bank budget and the arrangements on profit and loss distribution. In legal studies these arrangements have certainly received less attention.

To this end a critical assessment of the role which the legal basis of a central bank plays in enhancing or undermining the financial position of a central bank vis-à-vis government and,

\footnotetext{
${ }^{3}$ Including in past works by the author.

${ }^{4}$ Cf. e.g. T. Lybek, Elements of Central Bank Autonomy And Accountability, MAE Operational Paper 98/1, February 1998; R.H. Hasse, The European Central Bank: Perspectives for a Further Development of the European Monetary System, in R.H. Hasse (ed.), The European Central Bank: Perspectives for a Further Development of the European Monetary System (Bertelsmann Foundation publishers: Gütersloh, 1990, 121-122; C. Cottarelli, Limiting Central Bank Credit to the Government, Theory and Practice, Occasional Paper No. 110 , International Monetary Fund, September 1993.
} 
thereafter. In this context, legal arrangements which do not only support the financial independence of a central bank but also enhance its accountability are observed. Where appropriate, references are included to legal arrangements in existing central bank systems so to provide for negative and positive examples. ${ }^{5}$

\section{Central bank capital}

Whether and to what extent central banks actually require capital in order to function properly has been the subject of debate among economists. ${ }^{6}$ From the point of view of securing the independence of the central bank the lack of a legal requirement for an initial authorized capital bears the risk that the central banks becomes directly dependent on the financial support of the government, in situations were its profits and/or general reserve are not sufficient to cover losses. ${ }^{7}$

The mere fact that the legal basis of the central bank refers to central bank capital does not per se ensure central bank autonomy. Indeed, where the legal basis foresees in the initial capitalization of the central bank without however quantifying the authorized capital, it may be assumed that the decision in this regard is at the discretion of the government as the bank's likely only shareholder. Thus, for example, the legal basis of the People's Bank of China states rather vaguely that '[A]ll capital of the People's Bank of China is funded by the State and owned by the State. ${ }^{8}$ No further details are provided in the law relating to the amount of capital. Moreover, it remains unclear whether and to what extent government is required to actually transfer any capital to the central bank. Yet, without any clear obligation on parts of the government in this regard it is questionable whether, to what extent and under what conditions the central bank can actually utilize its capital in case the need arises. The central bank becomes dependent on the benevolence of government.

\footnotetext{
${ }^{5}$ It should be noted in this context however that this study does not in any ways aims at providing a balanced and representative legal survey of central bank systems. Cf. e.g. F. Amtenbrink, The Democratic Accountability of Central Banks (Oxford and Portland, Oregon: Hart Publishing, 1998). Generally on the role of central banks P.L. Siklos, The Changing Face of Central Banking (Cambridge: Cambridge University Press, 2002).

${ }^{6}$ Cf. e.g. A. Ize, Capitalizing Central Banks: A Net Worth Approach, IMF Staff Papers, Vol. 52, No. 2

${ }^{7} \mathrm{Cf}$. also hereafter the section dealing with central bank profit and loss distribution.

${ }^{8}$ Article 8 Law of the People's Republic of China on the People's Bank of China. An unofficial translation can be found on the homepage of the People's Bank of China at http://www.pbc.gov.cn/english/ (last visited: 2 May 2006), which refers to the version '.... as adopted at the 3rd Session of the 8th National People's Congress on March 18, 1995, and amended in accordance with the 'Decision to Amend the Law of the People's Republic of China on the People's Bank of China' made at the 6th meeting of the Standing Committee of the 10th National People's Congress on December 27, 2003.'
} 
Interestingly, such shortcomings do not necessarily have to coincide with a central bank law which from the outset assigns full control over monetary policy to the government. ${ }^{9}$ In the case of the Central Bank of the Russian Federation (Bank of Russia), the federal law sets out to declare that the bank '...shall fulfil the functions and exercise the powers stipulated by the Constitution of the Russian Federation and this Federal Law independently from other federal bodies of state power, the bodies of state power of the constituent entities of the Russian Federation and local self-government bodies'. ${ }^{10}$ Yet, strikingly the legal basis of the Bank of Russia includes no details concerning the paying up of its authorized capital of 3 billion rubles. ${ }^{11}$ Such a contradictio in adjecto in a central bank law highlights the importance of a consistent approach by the drafters of central bank legislation to central bank independence with regard to all aspects of central banking.

From an economic point of view it has been argued that the depletion of the central bank's capital amounts to providing direct credit to the government, often resulting from government policies forced upon the central bank. ${ }^{12}$ While it may be argued that central bank losses bearing upon the central bank capital may not in all instances be attributed to government, the lack of an obligation on parts of the latter to recapitalize the bank may make the pursuing of such policies attractive, as the central bank will in the first instance have to pick up the tab. What is more, the central bank may once more have to rely on the good will of the government to come to the rescue in case the initial capital proofs insufficient. The central bank may become economically dependent. For this reason the legal basis of a central bank should not only lay down in details the amount and arrangements concerning the paying up of any initial authorized capital, but should also specify the procedure applicable in case that a need for recapitalization arises.

It may be argued that the central bank's independent position is best served by including legal arrangements allowing for an automatic capital contribution upon the request by the central

\footnotetext{
${ }^{9}$ The latter is however the case in the People's Republic of China.

${ }^{10}$ Article 1 Federal Law on the Central Bank of the Russian Federation of 27 June 2002. See also Article 75 Constitution of the Russian Federation of 12 December 1993, which stipulates that money issue shall be carried out exclusively by the Central Bank of the Russian Federation and that the protection and ensuring the stability of the rouble shall be the major task of the Central Bank of the Russian Federation, which it shall fulfil independently of the other bodies of state authority.

${ }^{11}$ Ibid., Article 8.

${ }^{12}$ Lybek (1998), at 22.
} 
bank. Yet, it is questionable whether such arrangements amount to good governance practices in managing public funds, as any review by democratically elected executive government and/or parliament would be at large. One solution to this problem may be to provide for a procedure in the legal basis of the bank whereby any recapitalization on request of the central bank is subject to approval by the executive government or parliament. The Bank of Canada Act of 2001 may serve as an example for legal arrangement in this direction. The Board of Directors of the Bank of Canada can pass a resolution to increase the capital of the bank. This resolution thereafter requires the approval of the Governor in Council and of Parliament. ${ }^{13}$

From the outset, involving both executive government and parliament does not only introduce a broad democratic decision-making in what essentially amounts to a distribution of public funds, but moreover also offers a system of checks and balances between these two institutions. However, the main setback in putting the decision both in the hands of executive government and parliament is that the central bank may fall victim to a political divide..$^{14}$

The Statute of the European System of Central Bank and of the European Central Bank (Statute ESCB and ECB) offers an interesting legal setup, as it separates the basic initial decision allowing for a re-capitalization from the final decision to actually re-capitalize. In the case of the European Central Bank, which has arguably been designed from the outset with the aim of providing a maximum degree of independence, the decision for a capital increase and the actual amount rests with the Governing Board of the European Central Bank. ${ }^{15}$ However, it is the Council of the European Union and thus the governments of the Member States which stets the limits and conditions for an increase in capital in a basic decision. ${ }^{16}$ The corresponding Council Regulation, which is based on a recommendation by the European Central Bank, establishes a limit for future increases in the capital, while at the same time enabling the Governing Council to decide on an actual increase at some point in time in the

\footnotetext{
${ }^{13}$ Chapter B-2, section17 (1) Bank of Canada Act of 2001, The Governor General, which is effectively executing orders-in-council and cabinet decisions, represents the Queen, which is the formal Head of State.

${ }^{14}$ To be sure, while placing the decision with the executive government does not have to result in the removal from parliamentary scrutiny, as long as the constitutional system provides for the answerability of executive government vis-à-vis parliament.

${ }^{15}$ Article 28 (1), sentence 2 Statute ESCB and ECB.

${ }^{16}$ Article 42 Statute ESCB and ECB in conjunction with Article 107 (6) EC.
} 
future. ${ }^{17}$ The Governing Council can take this decision in order to sustain the adequacy of the capital base needed to support the operations of the European Central Bank. ${ }^{18}$

The legal basis of central bank may thus very well provide for a system whereby the democratically elected government decides on the margins within which it is for the central bank to decide on an actual increase in capital. The key to this arrangement is that at the time when the actual need for a re-capitalization arises, the bank is not depended from government.

\section{Central bank budget}

In order to ensure the financial independence of a central bank, the latter should not be depend on the government's general budget, but rather be in a position to finance its operations through generated income. Likewise, a central bank's annual plan including intended expenses and revenues should not be in control of government, as the latter opens the possibility of political influence on central bank operations. ${ }^{19}$

In what may arguably be described as the most severe arrangement from the point of view of central bank independence, the budget of the central bank forms an integral part of the annual government budget. Depending on the constitutional system and the applicable budget appropriation procedure this may first of all provide executive government and parliament with a superb instrument to achieve central bank compliance. Moreover, even if government manages to withstand the temptation, the central bank may find itself in an awkward position in case that the appropriation procedure comes to a standstill as a result of differences between executive government and parliament. An obvious solution to the latter problem is to uncouple the approval of the central bank budget from the general budget appropriation procedure. An example for such an arrangement can be found at the Bank of Japan, which prepares a budget

\footnotetext{
${ }^{17}$ The Council of the European Union acts by a qualified majority either based on a recommendation from the ECB and after consulting the European Commission or acting unanimously on a proposal from the European Commission and after consulting the ECB.

${ }^{18}$ The Governing Council can decide to increase the initial capital of euro 5000 million by euro 5000 million. See Council Regulation 1009/2000 of 8 May 2000, OJ 2000 L115/1, concerning capital increases of the European Central Bank. Cf. also European Central Bank Recommendation for a Council Regulation (EC) of 3 November 1998 concerning the limits and conditions for capital increases of the European Central Bank (ECB/1998/11), OJ 1998 L 411/10.

${ }^{19}$ Cf. M. Beblavy, Central Bankers and Central Bank Independence, Scottish Journal of Political Economy, Vol. 50 , No. 1, February 2003, at 66, who points out that there is a significant scope for influencing the actual monetary policy execution, since a large part of many central bank's budgets is spend on monetary policy execution.
} 
for general and administrative expanses which thereafter is forwarded to the Minister of Finance for authorization before the business year begins. ${ }^{20}$

Yet, this arrangement does not remove the threat of government influence on the central bank, which is the reason way in some central bank systems it has been chosen to leave the central bank to its own devices in deciding on its budget. This is for example the case with regard to the Federal Reserve System ${ }^{21}$ and the Bank of England. ${ }^{22}$ The legal basis of the central bank may provide for an obligation in parts of the central bank to inform government of its budget, as is the case with regard to the Riksbank Sweden, which is has to submit the annual budget for administrative activities, drafted by the executive Board of the bank, to the parliamentary (Riksdag) subcommittee on finance, the Swedish National Audit Office and the General Council of the bank. ${ }^{23}$

From the point of view of accountability a complete freedom on parts of the bank to establish its budget or a mere obligation to submit an estimate of expenditures for information purpose is problematic. Indeed, such arrangements disregard the fact that central bank is essentially managing public funds. It may be argued that central bank financial accountability is ensured to the extent that modern central bank laws provide for an internal and/or external review of the bank's accounts. Yet, first of all, monetary policy operations are often explicitly or implicitly excluded from such audits. ${ }^{24}$ Moreover, such audits can at best amount to an effective mechanism of ex post accountability, if and to the extent that the legal basis attaches consequences for the central bank in case that the central bank's managing of its finances is considered unacceptable. Central bank laws are regularly silent on this specific issue. As a consequence of the separation of the budgets of independent central banks from government budget, the former will also not be subjected to any existing parliamentary procedure on the discharging of government.

\footnotetext{
${ }^{20}$ Article 51 Bank of Japan Law 1997, as amended.

${ }^{21}$ The funds of the Federal Reserve System are not considered government funds. The Federal Reserve Banks in the system have to forward their separate budgets for Board of Governors of the Federal Reserve Board for approval.

${ }^{22}$ Cf. F. Amtenbrink (1998), at 326

${ }^{23}$ Chapter 10, Article 2 Swedish Riksbank Act.

${ }^{24}$ Cf. e.g. Article 27.2. Statute ESCB and ECB, according to which the review by the European Court of Auditors is limited to an examination of the operational efficiency of the management of the ECB.
} 
The Reserve Bank of New Zealand Act 1989 highlights how this smilingly unbridgeable divide between the legal arrangements which are sensible from the point of view of financial independence and those, arguably necessary in order to ensure the accountability of the central bank for its management of public funds, can be overcome. Rather than to make the central bank budget subject to the requirement of an unilateral approval by executive government and/or parliament, the Minister of Finance and the governor of the Reserve Bank are required to reach consensus on a so-called Funding Agreement which specifies the total expenditure to be incurred by the Reserve Bank for each financial year and, moreover, details the types of expanses covered by the agreement..$^{25}$ The Minister of Finance has to seek approval for the Funding Agreement from the House of Representatives, the New Zealand parliament. ${ }^{26}$ While the latter cannot introduce changes to the agreement it can in principle deny its ratification. This contract-approach, which has for the first time been introduced with the Reserve Bank Act 1989, form part of a broader public sector reform aiming, among other things, at increased financial efficiency and accountability. ${ }^{27}$ While the Reserve Bank is thus not entirely free in determining its budget, the Funding Agreement provides the bank not only with a say in the drawing up of the budget, but moreover with a considerable degree of financial security and stability, as the Funding Agreement is concluded for a consecutive period of 5 years, thereby exceeding the duration of government. ${ }^{28}$ Moreover, both executive government and parliament have to commit themselves to this framework. At the same time the Funding Agreement can also functions as a yardstick against which the performance of the bank can be judged. ${ }^{29}$

\section{Central bank profit and loss distribution}

Equally decisive for the financial position of the central bank vis-à-vis government are the legal arrangements surrounding the distribution of central bank profits and losses. Where a central bank is required to fully surrender the surplus resulting from the settlement of income and losses, excluding the possibility to make provisions for a general reserve, shortfalls in revenue may require the bank to fall back on its initial capital and, eventually, to rely on the

\footnotetext{
${ }^{25}$ Cf. Section 159 Reserve Bank of New Zealand Act 1989 and Funding Agreement pursuant to Section 159 of the Reserve Bank of New Zealand Act 1989 of 20 April 2005. Generally with regard to the financial management at the reserve Bank of New Zealand cf. R. Perry, Central bank corporate governance, financial management, and transparency, Reserve Bank of New Zealand Bulletin Vol. 64, No. 1, 33-41.

${ }^{26}$ Section 161 Reserve Bank of New Zealand Act 1989.

${ }^{27}$ M. Lloyd, The New Zealand Approach to Central Bank Autonomy, Reserve Bank of New Zealand Bulletin No. 55 (1992), 203, 203-220, at 217.

${ }^{28}$ In New Zealand parliamentary elections take place every three years.

${ }^{29}$ F. Amtenbrink (1998), at 332.
} 
government for financial support. If the legal basis of the central bank does not foresee in an initial capitalization, the central bank comes to rely directly on financial assistance from government.

Generally, a differentiation has to be made between rules governing the allocation of any existing profits and a provision included in the legal basis committing the central bank to a profit oriented conduct of its operations. The latter has to be considered problematic, as a profit oriented central bank may not at the same time be able to function as a guarantor of a stable monetary policy. The reason for this can be found in the positive correlation which has been observed between inflation on the one side and the income from seigniorage and the managing of obligatory reserve requirements on the other side. ${ }^{30}$ To the extent that the legal basis of a central bank defines price stability as an objective, the introduction of profits as an additional and coequal goal may lead to a conflict of interests. Moreover, such an arrangement may de facto result in an unholy alliance between the central bank and government, as the latter can be considered as the main beneficiary of profits generated by the central bank.

The formulation of a profit goal is also not an indispensable element in judging the performance of the bank and hence, is not a necessary element of central bank accountability. Indeed, considering the public function of a central bank, Sullivan is right in pointing out that:'[P]olicy effectiveness, rather than efficiency of resource utilization or profitability provides the basis for central bank accountability. ${ }^{31}$ Put differently, the central bank should be judged with regard to its conduct of monetary policy, rather than its profit margin.

While an explicit prohibition, such as to be found in the federal law on the Bank of Russia creates clarity in this regard, it cannot necessarily be concluded argumentum e contrario from the lack of such a provision in the legal basis that the central bank is permitted to pursue profits as an objective. ${ }^{32}$ Indeed, in many instances central bank laws do not include any references to profits other than to include details the applicable procedure for their distribution. Yet, where the legal basis provides for price stability as the overriding primary

\footnotetext{
${ }^{30}$ Cf. e.g. R.D. Sleeper, How central banks manage their finances, speech to the South African Reserve Bank, 18 February 2005, online available at http://www.bis.org (last visited: 2 May 2006).

${ }^{31}$ K. Sullivan, Profits, Dividends and Capital Considerations for Central Banks, Paper presented at the IMF Seminar on Current Developments in Monetary and Financial Law, Washington, D.C., May 7-17, 202, online available at http//www.imf.org (last visited: 2 May 2006).

${ }^{32}$ Article 3 Federal Law on the Central Bank of the Russian Federation (Bank of Russia) states: 'Deriving profits shall not be the purpose of the Bank of Russia.
} 
objective of the central bank, for the reasons stated above, a profit orientation arguably would have to be considered incompatible with this objective. Hence, the fact that the Statute of the ESCB and the ECB lacks of an explicit exclusion of profit orientation arguably does not as such imply a less independent central bank..$^{33}$

While profits should thus not be defined as a statutory objective of the central bank, the legal basis must include clear provisions on how to calculate any arising net profits or net losses and, moreover, provide for rules on how profits and losses are allocated. With regard to the former, a clear reference in the legal basis to the applicability of international accounting standards is desirable. ${ }^{34}$ With regard to the latter, the central bank's financial independence comes under threat in case that profit distribution takes place potentially at the cost of the bank's financial position. With regard to profits the legal basis should include criteria on the basis of which their distribution in particular to the bank's shareholder(s) can be objectively determined. De jure or de facto arrangements leaving it effectively to government to decide on the amount to which it is entitled contradict the very essence of central bank financial independence, as the central bank may effectively become a self-service shop. Equally undesirable are provisions in the legal basis giving government the right to partial payments before the end of the fiscal year based on an estimate for that year. Such a possibility is for example provided for in the legal basis of the Bank of Japan, which entitles government to such an advance on profits based on a Cabinet Order. ${ }^{35}$ Interestingly, the Bank of Japan Act does not seem to foresee in rules in case that the advance to government turns out to have been excessive at the end of the financial year. In such a situation the advance can weaken the financial position of the bank.

Equally problematic is the situation where the profit calculation includes unrealized gains. Taking account of such paper profits which increase or decrease over time or even transform into a loss amount to a misrepresentation of the bank's financial position. Consequently, the legal basis of a central bank should state unequivocally that unrealized gains are deducted from the profits, which become the basis of profit distribution. A notable example of how the issue of unrealized gains can be addressed in the legal basis can be found in the new statute of the Central Bank of Iraq. The bank is obliged to deduct from the net income the total amount

\footnotetext{
${ }^{33}$ Cf. also for example Article 11 Bank of England Act 1998.

${ }^{34}$ For more details cf. Sullivan (2002), with further references.

${ }^{35}$ Article 53 (6) Bank of Japan Law.
} 
of unrealized gains for a financial year on assets or liabilities that are recorded at fair value or are denominated in foreign currency ${ }^{36}$ Until such time that they are realized, an amount equivalent to such gains has to be allocated to an unrealized profits reserve. Gains are added to the net profits at the end of the financial year in which they have been realized.

In order to secure the financial independence of the central bank, the legal basis should also foresee in the allocation of a percentage of the net profits to a general reserve. The existence of a general reserve helps to secure the financial independence of a central bank vis-à-vis government, as losses can be dealt with without the need for the bank to rely on its initial capital and/or government financial support. Preferably the legal basis of the central bank should define this and possibly any additional purpose of the general reserve, thereby excluding that the bank utilizes this fund for other purposes. ${ }^{37}$

Moreover, the level of the general reserve to be held by the bank needs to be determined. Leaving it at the discretion of the central bank, possibly in consultation with government, to decide on the amount of the general reserve is arguably a less desirable arrangement given that the central bank may, with a view to profit distribution, feel under pressure to determine the reserve at a level below what may be necessary to ensure financial stability. The actual percentage may be linked to the amount of initial capital, either being equivalent to latter or any percentage of that ${ }^{38}$, or to a percentage of the total assets of the central bank..$^{39}$

The legal basis must provide objective criteria on the basis of which the percentage of the annual net profits earmarked for a reserve fund can be determined. Leaving this decision at the discretion of government may result in a conflict of interests, as the latter may find the shortterm optimization of gains from central bank profits more appealing than the medium and long-term financial position of the central bank. A negative example in this regard is the legal arrangement relating to the People's Bank of China. Here, the proportion of the net profits to be allocated to the general reserve is determined by the financial department of the State

\footnotetext{
${ }^{36}$ Article 5 para. 4 Statute Central Bank of Iraq.

${ }^{37}$ Cf. e.g. Article 53 (3) Bank of Japan Act which however also allows the utilization of the reserve fund for the payment of dividends to shareholders in accordance with Article 53 (4) Bank of Japan Act.

${ }^{38}$ Cf. e.g. Article 33.1 (a) Statute ESCB and ECB = equal to 100 percent of the capital. Chapter 10, Article 1 Sveriges Riksbank Act = effectively 50 percent of the initial capital of one thousand million krona. In the case of the Bank of Canada, the so-called rest fund can reach an mount of five times the paid-up capital, cf. Chapter B-2, section 27 Bank of Canada Act of 2001. It should be noted however that the initial capital prescribed in the Bank of Canada Act of 2001 is relatively small in comparison.

${ }^{39}$ Cf. e.g. Article 8 (1) (a) Central Bank of Iraq Law: 10 percent.
} 
Council. ${ }^{40}$ Given the fact that the central bank profits essentially constitute public funds, it should likewise not be at the discretion of the central bank itself to decide on the amounts of net profits withheld for the purpose of being added to the general reserve. A rule such as that to be found for the ESCB and ECB may provide a good solution in this regard. Here, the maximum amount to be allocated to the general reserve which itself is subject to a limit of 100 percent of the ECB's capital is curtailed, while at the same leaving it at the discretion of the central bank to decide on the actual amount within the given margins. ${ }^{41}$ An interesting legal approach involving parliament can be found for the Swedish Riksbank. The Swedish parliament (Riksdag) does not only approve the bank's profit and loss account and balance sheet, but also determines the allocation of the Riksbank's profits, whereby parliament is obliged to allocate at least 10 percent of the net profits to the reserve fund in case that the latter has not reached its prescribed level. ${ }^{42}$

Next to the distribution of profits, the legal basis of a central bank needs to include rules on the distribution of losses. This is far from evident, as the lack of any extensive reference in some central bank laws highlights..$^{43}$ In principle different legal arrangements are conceivable as a comparison of different central bank law reveals. Firstly, the law may prescribe that any losses are made up by appropriation of government. ${ }^{44}$ Where the central bank is at the same time required to distribute all net profits to government, such a legal arrangement may ensure a balance between profit and loss distributions. In many instances the legal basis requires that net looses are offset against the general reserve installed for that very purpose. ${ }^{45}$ Whether this amounts to an asymmetric treatment of profit and losses, as seems to have been suggested in the literature, is questionable. ${ }^{46}$ To the extent that the law requires the allocation of a certain percentage of net profits to a general reserve this effectively results in the diminution of the amount distributed to government. Government is thus effectively picking up the bill for as long as the central bank has a reserve to draw from.

\footnotetext{
${ }^{40}$ The State Council is the highest central executive and administrative organ in the People's Republic of China. cf. Article 85 Constitution of the People's Republic of China of 1982, as amended, online available at http://www.npc.gov.cn (last visited: 2 May 2006).

${ }^{41}$ Article 33.1. (a) Statute ESCB and ECB, according to which the amount transferred to the reserve, which is determined by the Governing Council of the ECB, may not exceed 20 percent of the net profit.

${ }^{42}$ Chapter 10, Article 4 Sveriges Riksbank Act.

${ }^{43}$ Cf. e.g. Chapter 10 Sveriges Riksbank Act which does however explicitly foresee in a reserve fund.

${ }^{44}$ Cf. e.g. Article 38 Law of the People's Republic of China on the People's Bank of China.

${ }^{45}$ Cf. e.g. Article 33.2. Statute ESCB and ECB.

${ }^{46} \mathrm{Cf}$. Stella (2002), at 15, who refers to an asymmetric treatment of profits and losses in cases where the profits are distributed whereas losses remain those of the central bank and are attributed to the general reserve.
} 
A different conclusion may be reached where losses are directly offset against the capital or where any losses exceeding the general reserve are offset again the capital. In the case of the former, Martinez-Resano points out rightly that:'(... $)^{6} \ldots$ should profits observed in good years not be available to repair damages to central banks' financial strength in bad ones, amounts in economic terms to granting a zero rate indefinite term loan to the government. ${ }^{47}$ The same holds true for losses which exceed the general reserve and which are thereafter offset against the capital. The legal basis should lay down a clear order in which losses have to be offset, starting with the reserve fund and moreover provide for a re-capitalization in case that losses are offset against the capital. ${ }^{48}$

\section{Conclusion}

Financial autonomy forms a key element of the overall independence of a central bank. While in the past numerous studies have focused on the role of the central bank as the government's bank and any obligations to offer (unlimited) credit facilities, it has been highlighted throughout this short contribution that the position of the central bank vis-à-vis government is also decisively determined by the legal arrangements governing the different aspects of central bank financing identified above.

Compared to the issue of government access to central bank credit, determining the impact on the position of a central bank vis-à-vis government of the legal arrangements relating to (re-) capitalization, central bank budget and the treatment of profits and losses can be a rather intricate exercise due foremost to the interdependency of the different aspects contributing to the financial position of the central bank. Indeed, only if the legal basis addresses these aspects in a consistent and coherent manner can the financial independence of the central bank be fully secured. Central bank independence and thus also financial independence stand for a general principle which has to be observed for all aspects of central banking in order to be fully effective. Including a general provision in the legal basis providing the central bank with an independent status arguably counts for relatively little if an analysis of the detailed

\footnotetext{
${ }^{47}$ J.R. Martínez-Resano, Central Bank Financial Independence, Bank of Spain, Occasional Paper no. 0401, 2004, online available at http://www.bde.es (last visited: 2 May 2006), at 16.

${ }^{48}$ Cf. e.g. Article 28 (a) Law on the Central Bank of Bosnia and Herzegovina, online available at http://www.cbbh.gov.ba (last visited: 2 May 2006). In the case of the ESCB, after having made use of the reserve fund, ECB losses can also be offset against monetary income of the relevant financial year in proportion and up to the amounts allocated for the national central banks in accordance with the Statue of the ESCB and the ECB.
} 
provisions quickly reveals that the central bank is financially largely dependent on government.

This contribution has focused exclusively on legal arrangements thereby to some extent deliberately disregarding the brief definition of central bank financial independence offered in the introduction. This implicit insistence on an implementation of these arrangements in the legal basis of the central bank seems to contradict many (economic) studies of central bank independence which emphasise the importance of observing the factual circumstances to be found in a central bank system in particular those, relating to the relationship between the central bank and government. ${ }^{49}$ Yet, while indices on central bank independence aim at analysing the actual degree of autonomy of a given bank, which may not only or not even primarily steam from its legal basis, in discussing legal arrangements securing the independence of a central bank, clear, unambiguous and potentially enforceable rules have to take preference over de facto arrangements and informal practices which may not stand the test of time.

Statutory provisions ensure a continuous and coherent approach in the relationship between the central bank and government and help to prevent conflicts with possibly damaging effects not only for the financial position of the central bank, but also both for the credibility of the central bank as the monetary policy authority and for the general economic policy of government. Such conflicts may not only arise as a result of a clash of monetary and fiscal policy objectives ${ }^{50}$, but may also be more specifically linked to central bank finances, namely profit distribution. Clear rules moreover also promote central bank transparency which arguably does not only form a condition sine qua non in holding a central bank accountable for its conduct, but can also help to force conflicts between the central bank and government out in the open. This can function as a restraint on parts of the government and strengthen the independent position of the central bank. ${ }^{51}$

\footnotetext{
${ }^{49}$ With regard to the legal and non-legal approach cf. e.g. F.Amtenbrink (1998), 22-23, with further references. ${ }^{50}$ Cf. e.g. P.L. Siklos, Framework for the Resolution of Government-Central Bank Conflicts: Issues and Assessment, updated paper presented at the Seminar on Current Development in Monetary and Finance Law at the International Monetary Fund, May 2002, online available at http://www.imf.org (last visited: 2 May 2006).

${ }^{51}$ F. Amtenbrink, The Three Pillars of Central Bank Governance - Towards a Model Central Bank Law or a Code of Good Governance?, in International Monetary Fund, Current Developments in Monetary and Financial Law, Volume 4 (Washington D.C.: IMF Legal Department, 2005).
} 
While this contribution was not primarily geared towards discussing central bank financial accountability, the few examples of legal arrangements to be found in existing central bank systems indicate that financial independence does not necessarily exclude the participation if democratically elected institutions in decisions linked to the finances of a central bank. Indeed, rightly implemented in the legal basis of a central bank there does not need to be an unbridgeable divide between these two concepts. Moreover, as the example of the contract approach at the Reserve Bank of New Zealand show, government and/or parliament participation does not necessarily have to be limited to an ex post review of the bank's performance. 